\title{
DETECÇÃO DE Streptococcus spp. UTILIZANDO A TÉCNICA DE REP-PCR NO MONITORAMENTO DA QUALIDADE DO LEITE DE CABRA EM SALA DE ORDENHA ${ }^{1}$
}

\author{
Lea Chapaval ${ }^{2}$, Cellyneude de Souza Olivindo ${ }^{3}$, Francisca Geovânia Canafístula de Sousa ${ }^{4}$, Francisco \\ Selmo Fernandes Alves ${ }^{5}$, Isana Mara Aragão Frota ${ }^{6}$
}

\footnotetext{
${ }^{1}$ Parte dos resultados obtidos através do Projeto intitulado "Aplicação da epidemiologia molecular no monitoramento da qualidade do leite de cabra", financiado pela Empresa Brasileira de Pesquisa Agropecuária (Embrapa);

${ }^{2}$ Pesquisadora - Embrapa Caprinos (líder do projeto). E-mail: lea@ cnpc.embrapa.br (autor para correspondência);

${ }^{3}$ Aluna do curso de Doutorado em Zootecnia da Universidade Federal de Viçosa (UFV)/MG;

${ }^{4}$ Aluna do curso de Mestrado em Zootecnia Universidade Federal da Praíba (UFPB)/PB - Bolsista da Embrapa;

${ }^{5}$ Pesquisador Embrapa Caprinos;

${ }^{6}$ Aluna do curso de Mestrado em Biotecnologia da Universidade Federal do Ceará (UFC)/CE.esquisador Embrapa Caprinos;
}

Resumo: O presente estudo foi realizado, com o objetivo de aplicar a técnica de REP-PCR no monitoramento da qualidade do leite de cabra, através da detecção de Streptococcus spp., em amostras de mãos de ordenhador, tetos das cabras, leite, ordenhadeira e água, para o futuro estabelecimento e implantação do sistema de Análise de Perigos e Pontos Críticos de Controle (APPCC). Verificaram-se vários fingerprints de todos os isolados coletados das diferentes fontes estudadas (mãos de ordenhador, tetos das cabras, leite, ordenhadeira e água). Observaram-se comportamentos muito similares das bandas indicando que os isolados podem ser relatados como clones epidemiológicos. As mãos do ordenhador caracterizaram-se como ponto crítico de controle, pois se destaca como iniciador de contaminação nas amostras Streptococcus spp. A técnica demonstrou ser eficiente para a análise da similaridade entre indivíduos da espécie Streptococcus spp, sendo, portanto, uma ferramenta útil para investigação de falhas no manejo e consequentemente, na busca de um controle mais eficiente para evitar ou minimizar a disseminação de microrganismos patogênicos causadores de sérias enfermidades em humanos e animais, que muitas vezes podem ser transmitidas através de produtos como o leite e seus derivados.

Palavras-chave: Streptococcus spp., epidemiologia molecular, identidades genômicas, leite de cabra

\begin{abstract}
The present study was carried out, with the objective of applying the REP-PCR sequences in the monitoring of the quality of goat milk, through the detection of Streptococcus spp, in samples of milking handlers, goats teats, milk, milk machine and water, for the future establishment and implantation of the system of Hazard Analysis Critical Control Points (HACCP). Several fingerprints were verified of all the isolates collected of the different studied sources (milking handlers, goats teats, milk, milk machine and water). It was observed very similar behaviors of the bands indicating that the isolates can be related as epidemic clones. Hands of the milking handlers was characterized as a critical point of control (PCC), because stands out as initial point of contamination in the Streptococcus spp. The technique demonstrated to be efficient for the similarity analysis among individuals of the Streptococcus spp. species, being, therefore, an useful tool for investigation of fails on management and consequently, in the search of more efficient control to avoid or to minimize the spread of pathogenic microorganisms that cause serious illnesses in humans and animals, and can be transmitted through products as the milk and your products.
\end{abstract}

Key words: Streptococcus spp., molecular epidemiology, fingerprints, goat milk.

\section{Introdução}

O sistema APPCC (análise de perigos e pontos críticos de controle) tem sido um instrumento útil para avaliar os riscos de perigos e estabelecer mecanismos ou medidas de controle que visem minimizar os riscos de contaminação física, química ou microbiológica. A implementação do processo APPCC surge como uma alternativa dentro do ciclo de produção do leite de cabra apresentado, porém, questões ainda não referenciadas, como por exemplo, a falta de informações e dados, e as dificuldades de seleção dos Pontos Críticos de Controle (PCCs) para um número de perigos biológicos encontrados nas fazendas, onde há a impossibilidade de erradicar ou controlar a maior parte dos patógenos, especialmente aqueles que causam problemas clínicos em animais e que também podem causar danos à saúde humana, como: o Streptococcus spp. Assim, métodos baseados em DNA estão surgindo como vias confiáveis, simples e acessíveis para identificar e classificar microrganismos (CHAPAVAL et al., 2006). O método referido como REP-PCR, "impressão digital" do genoma, uma técnica baseada na amplificação do DNA, é tida como uma técnica extremamente confiável, reprodutível, rápida e discriminatória. O presente estudo foi realizado, com o objetivo de aplicar a técnica de PCR em seqüências palindrômicas extragênicas repetidas 
(REP-PCR) no monitoramento da qualidade do leite de cabra, através da detecção de Streptococcus spp. em amostras de mãos de ordenhador, tetos das cabras, leite, ordenhadeira e água, para o futuro estabelecimento e implantação do sistema APPCC.

\section{Material e Métodos}

O presente estudo foi conduzido na Embrapa Caprinos, em Sobral-CE, na Região norte do Estado do Ceará, no período de agosto de 2005 a janeiro de 2006. Para a obtenção das cepas bacterianas de Streptococcus spp. utilizadas neste estudo utilizou-se 15 fêmeas caprinas da raça Saanen, em início de lactação, as quais foram ordenhadas duas vezes ao dia, utilizando-se a ordenha mecânica, sendo submetidas à higienização do úbere, pré e pós-ordenha, com solução iodada. Foram coletadas 40 amostras na primeira ordenha às $7 \mathrm{~h} 30 \mathrm{~m}$, sendo estas divididas da seguinte maneira: amostras de leite $(\mathrm{n}=15)$, swab das teteiras $(n=3)$, swabs das mãos do ordenhador $(n=3)$ e swabs dos tetos dos animais $(n=15)$ coletadas no início, no meio e no final da ordenha. As amostras da água utilizada para a lavagem das mãos dos ordenhadores $(\mathrm{n}=4)$ foram coletadas antes do tratamento com água sanitária, e após o tratamento da água, no início, meio e final da ordenha. A coleta foi realizada utilizando técnicas assépticas e conforme protocolos padrão e as amostras foram encaminhadas em caixa térmicas para o Laboratório de Bacteriologia da Embrapa Caprinos. O material coletado foi semeado segundo OLIVINDO (2007), para extração de DNA das cepas bacterianas utilizou-se o protocolo proposto por CHAPAVAL et al. (2006), e, seqüencialmente, as reações de PCR foram realizadas segundo CHAPAVAL et al. (2008). A análise das similaridades entre as cepas foi baseada na presença ou ausência de bandas específicas na análise da reação de PCR, onde diferenças e similaridades entre as cepas foram analisadas visualmente de acordo com o comportamento de migração das bandas dos produtos da reação de PCR. Os perfis das 11 primeiras bandas foram considerados altamente similares quando todas as bandas visíveis dos isolados possuíam a mesma distância aparente de migração. Quando não houve possibilidade de comparação entre migração de bandas semelhantes, os isolados foram considerados diferentes. Uma matriz de similaridade foi obtida através de comparações usando um coeficiente simples de similaridade (coeficiente de Jaccard). Para esta análise o programa utilizado foi o NTSYS - Numerical Taxonomy and Multivariate Analysis System, versão NTSYSpc 2.0. Um dendograma foi construído através da obtenção das médias aritméticas de grupos em pares de dados combinados (UP-GMA). Após a análise computacional dos dados de similaridade genética, o estudo da filogenia foi realizado. Organismos considerados geneticamente iguais, ou semelhantes, foram considerados clones epidemiológicos e, portanto de mesma ancestralidade e origem.

\section{Resultados e Discussão}

$\mathrm{Na}$ análise da similaridade genética, em geral, os modelos das bandas dos isolados das diferentes fontes (leite, teto, teteira, mão do ordenhador e água) foram similares, inferindo que os isolados são estreitamente relacionados. Foram similares, porém nem sempre idênticos.

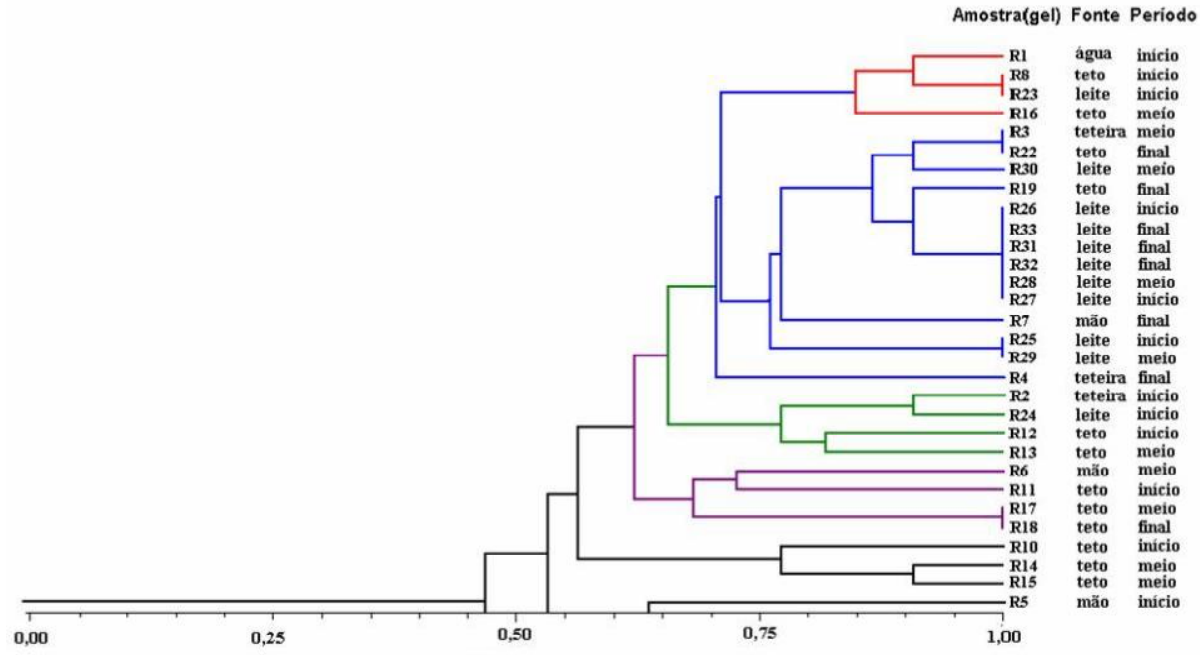

Figura 1. Dendograma gerado a partir dos dados obtidos da tipagem de Streptococcus spp. Os números do eixo $\mathrm{x}$ indicam o Coeficiente de Jaccard 
O comportamento das bandas obtidas através do uso do primer REP para Streptococcus spp. demonstrou similaridade entre $85 \%$ dos isolados diferenciando-se as cepas dentro de cinco clusters distintos conforme dendograma gerado na Figura 1. No cluster 1, a amostra R1 (água sem tratamento) utilizada para a lavagem das mãos do ordenhador mostrou-se aproximadamente $90 \%$ similar as amostras R8 (swab de teto) e R23 (leite do início da ordenha respectivamente) que por sua vez demonstraram similaridade de $85 \%$ com a amostra R16 (swab de teto coletada no meio da ordenha). Pode-se inferir, neste caso, que água (sem tratamento) utilizada para a lavagem das mãos do ordenhador no início da ordenha foi possivelmente a fonte de contaminação para as demais amostras deste cluster. Sendo por tanto necessário rever a idoneidade da procedência dessa variável. No cluster 2, as amostras R3 (swab teteira meio de ordenha), R22 (swab teto final de ordenha), são 100\% similares e com a amostra R4 (teteira final de ordenha) podem ser indicadas como fontes de contaminação ao longo do processo. As amostras R26 (leite início de ordenha), R31, R32 e R33 (leite final de ordenha respectivamente), R28 (leite meio de Observou-se no cluster 3 que as amostras R2 (teteira início de ordenha), R24 leite início de ordenha), R12 e R13 (swab de tetos início e meio de ordenha respectivamente) apresentaram similaridades variando entre aproximadamente 80 e $95 \%$. Verificou-se no cluster 4 que as amostras R17 e R18 (swab teto início e final de ordenha, respectivamente) são $100 \%$ similares entre si. Com relação ao cluster 5 composto pelas R10, R14, R15 (swab teto início, meio e final de ordenha) e R5 (swab das mãos do ordenhador) a similaridade variou de aproximadamente 60 a 95\%. Diante dos resultados obtidos foi possível verificar caráter de transmissibilidade nos presentes clusters. Métodos tais como REP-PCR tem sido testados e a habilidade deste método para diferenciar cepas de Streptococcus vêm sendo investigados (RAJASBEKARA et al., 1998). AL-GHAMDI et al. (2000) revelaram, através de REP-PCR, que isolados de Streptococcus equi com mesma fonte geográfica não possuíam um mesmo sub-tipo, na ocasião somente um clone epidemiológico foi encontrado durante o surto da doença. Relatos como esses reforçam a importância da eficiência da técnica para estudos com bactérias do gênero Streptococcus ssp. No estudo de ALAM et al., (1999) foi verificado que métodos que não utilizam à reação de PCR são demorados e demandam técnicos com treinamento, especialmente no que diz respeito à análise de polimorfismos através de restrição de fragmentos que resultam em perfis de fragmentos de DNA de difícil interpretação com um grande número de bandas.

\section{Conclusões}

A água ainda sem tratamento, utilizada para a lavagem das mãos dos ordenhadores, caracterizouse um ponto crítico de controle (PCC), pois aparece como iniciador de contaminação nas amostras de Streptococcus spp. A técnica de REP-PCR também aparece como uma ferramenta útil na produção animal para a rápida identificação de pontos de contaminação bacteriana horizontal durante o manejo de ordenha, permitindo a reavaliação de procedimentos de higienização de equipamentos, higiene pessoal do trabalhador da sala de ordenha bem como da rotina de limpeza de tetos e eficácia dos desinfetantes utilizados para que em tempo hábil, falhas no manejo sejam detectadas e corrigidas.

\section{Literatura citada}

ALAM, S., S. R. BRAILSFORD, R. A. WHILEY, AND D. BEIGHTON. PCR-based methods for genotyping viridans group streptococci. Journal of Clinical Microbiology. v. 37, p. 2772-2776, 1999.

AL-GHAMDI, G. M.; KAPUR, V.; AMES, T. R..; TIMONEY, J. F.; LOVE, D. N.; MELLENCAMP, M. A. Use of repetitive sequence-based polymerase chain reaction for molecular epidemiologic analysis of Streptococcus equi subspecies equi. American Journal of Veterinary Research, v.61, n.6, p. 699-705. 2000.

CHAPAVAL, L.; MOON, D. H.; GOMES, J. E.; DUARTE, F. R.; TSAI, S. M. Aplicação da técnica de Rep-PCR no rastreamento de Staphylococcus aureus em sala de ordenha para o monitoramento da qualidade do leite. Brazilian Journal of Veterinary Research and Animal Science. São Paulo, v. 43, n. 3, p.309-320, 2006.

CHAPAVAL, L.; MOON, D. H.; GOMES, J. E.; DUARTE, F. R.; TSAI, S. M. An alternative method for Staphylococcus aureus DNA isolation. Arquivo Brasileiro de Medicina Veterinária e Zootecnia, v. 60, n. 2, p.299-306, 2008.

OLIVINDO, C.S. Detecção de microrganismos utilizando a técnica de PCR em seqüências palindrômicas extragênicas repetidas (REP-PCR) no monitoramento da qualidade do leite de cabra em sala de ordenha. 2007. Dissertação (Mestrado em Zootecnia) - Universidade Federal do Ceará, Ceará, 2007.

RAJASHEKARA, G., T.; KOEUTH, S.; NEVILE, A; BACK, K. V.; NAGARAJA, J. R. LUPSKI,V. KAPUR. SERE, a widely dispersed bacterial repetitive DNA element. Journal Clinical Microbiology. v. 47, p. 489-498, 1998. 